\title{
頸部食道癌の臨床的検討
}

\begin{tabular}{|c|c|c|}
\hline 朝倉 & 光司1) - 水見 & 徹夫 ${ }^{1)}$ - 原㴊 \\
\hline 浜 & 誠1) • 形浦 & 昭克 ${ }^{1)}$ • 晴山 \\
\hline 野 & 隆一3) - 平田 & 公一3) - 草島 \\
\hline
\end{tabular}

\section{A Clinical Study of Cervical Esophageal Carcinoma}

\author{
Koji Asakura, Tetsuo Himi, Yasuaki Harabuchi, \\ Makoto Hamamoto, Akikatsu Kataura, Masato Hareyama, \\ Ryuichi Denno, Koichi Hirata and Katsuyuki Kusajima \\ (Sapporo Medical University)
}

\begin{abstract}
A clinical study was performed on 25 patients with cervical esophageal carcinomas who had been treated at the Sapporo Medical University from 1983 to 1995.

The disease-specific 5-year cumulative survival rate was $34.2 \%$ overalls and $41.2 \%$ in the radical surgery cases. There were no long-term survivors in the radiotherapy cases. Tumor control was better in those cases receiving blunt dissection of the total esophagus than in those receiving a cervical dissection; the 5-year cumulative survival rate of the former group was $51.6 \%$. Recurrence of the disease in the cervical lymph nodes was not noted in the cases receiving a radical neck dissection.
\end{abstract}

Key words : clinical study, cervical esophageal carcinoma, radical surgery

\section{はじめに}

従来より食道癌は開胸, 非開胸を問わず, 主に外科で 治療されることが多かった.しかし, 頸部食道癌の場合 には, 喉頭 -下咽頭の処理, 頸部廓清術の手術手技, 頭 頸部の再建外科の進歩等の要因があるため，外科医と耳 鼻咽喉科医のチーム医療が最善と考兄られる. 当院では 1983年より喉頭の処理が必要な頸部食道癌は耳鼻咽喉科 が中心となって外科と放射線科との連携のらえで治療に あたっている. 今回の検討では，今後の治療指針の一助 とすべく, 我々が経験した頸部食道癌症例の臨床的解析 を行った。

\section{対象および方法}

当科に扣ける頸部食道癌治療の基本方針は, 咽頭喉頭
食道摘出術による根治手術を原則としている．術前の検 索にて飛び石転移陽性例と Th1 以上の局所進展例に対 しては食道全抜去後，後縦隔経路のつり上げ胃管による 再建を行い，頸部に限局した例に対しては皮弁あるいは 遊離空腸による再建を行うこととしている．甲状腺全摘 と両側の気管前傍リンパ節摘除は基本的には全手術例に 行い, 頸部リンパ節の腫脹に対しては頸静脈, 副神経を 含めた根治的全頸部廓清術を行った。

移植を含めた頸部の手術操作は耳鼻咽喉科が行い, 食 道抜去, 胃管形成, 遊離空腸の採取は外科が行う。術後 管理に関しては，食道全抜去例は外科が，頸部のみの切 除の際には耳鼻咽喉科が行らこととした.

放射線の併用に関しては他科との相談のら宥症例ごと に決定した.
1）札幌医科大学医学部耳鼻咽喉科学教室

3）札幌医科大学医学部第一外科学教室
2）札幌医科大学医学部放射線科学教室

4）札幌医科大学医学部第二外科学教室 
表 1 頸部食道癌病期

\begin{tabular}{l|ccccl|l}
\hline \hline & $\mathrm{T} 1$ & $\mathrm{~T} 2$ & $\mathrm{~T} 3$ & $\mathrm{~T} 4$ & $\mathrm{Tx}$ & \multicolumn{1}{c}{ 計 } \\
\hline $\mathrm{N} 0$ & 1 & 1 & 6 & 3 & 2 & 13 \\
$\mathrm{~N} 1$ & 1 & 3 & 2 & 4 & $2(1)$ & $12(1)$ \\
\hline 計 & 2 & 4 & 8 & 7 & $4(1)$ & $25(1)$
\end{tabular}

UICC stage 分類(1997)による.

1983年から1995年までに札幌医科大学耳鼻咽喉科にて 治療を行った頸部食道癌は25例（表 1 )であった．そのら ち根治手術症例は21例あり，何らかの理由で手術を断念 して放射線治療のみを行ったものが 4 例 (手術拒否 1 例, 遠隔転移 1 例, 肺機能低下 1 例, 高度進展 1 例) めった。 根治手術例のらち19例で咽頭喉頭食道摘出術を，2例で は食道摘出術のみを施行した。食道の切除方法に関して は，15例の咽頭喉頭食道摘出術施行例和よび 2 例の食道 摘出術施行例, 合計17例で非開胸の食道全抜去(胃管つ り上げ)を行い, また 4 例の咽頭喉頭食道摘出術施行例 では頸部のみのアプローチによる食道の切除を行った。

頸部廓清に関しては，5例で両側，6 例で一側の廓清 を併用した．な执，全例で甲状腺全摘と両側の気管前， 傍リンパ節の廓清を行ったが，胸骨切開を併用した上縦 隔の廓清を行った例はなかった. 手術単独が 6 例, 術前 放射線の併用 $(30 \sim 70 \mathrm{~Gy}$, 平均 $46.5 \mathrm{~Gy})$ が 12 例, 術後 放射線の併用 (平均 $56 \mathrm{~Gy}$ ) が 3 例であった。 下咽頭拉よ び頸部食道の再建方法は, 胃管17例, 遊離空腸 3 例, 二 期的手術 1 例であった。 な和, 根治治療の際には化学療
法の併用は行わなかった.

摘出食道に括ける飛び石転移の有無の検索に関しては, 肉眼的な観察によって病変が疑われた部位に限って病理 組織学的な検索を行った．当時はルゴール染色による病 的部位の同定は行っていない.

生存率の算出にはカプラン・マイヤー法を用い, 他病 死(ただし，原病巣が制御されている例）を打ち切りとし た累積原病 5 年生存率 (以下, 累積 5 年生存率と略す)を 計算した.

\section{治療成績}

全症例の累積 5 年生存率は $34.2 \%$ であり(図 1 ), M1 症例を除く根治治療例 24 例では35.8\%, 根治手術例 21 例 では $41.2 \%$ であった，根治照射例 ( $64 \sim 70 \mathrm{~Gy}$, 平均 66 Gy） 3 例では長期生存例は認められなかった.

根治手術群において TN stage との関連をみた結果, $\mathrm{T}$ stage と生存率の間に有意な傾向を認めず， N stage とリンパ節転移を含めた腫瘍制御および生存率との間に も一定の傾向は認められなかった(表 2 ).

手術内容との関連では, 食道全抜去を行った17例では 原病巣(絽隔)の残存再発を 1 例に認めたのみで, 累積 5 年生存率は $51.6 \%$ であった. 一方, 頸部のみのアプロー チで切除を行った 4 例では, 下方の食道断端の残存再発 2 例と気管孔周囲再発 1 例を認め, 5 年生存例はなかっ た. 照射の併用との関係では, 術前照射例の 5 年生存率 は $36.7 \%$, 手術単独例と術後照射例をあわせたものでは $58.3 \%$ であった(表 2 ). な和根治手術後の再建に関して は，3例で遊離空腸を，17例で胃管を用いたが，1例に

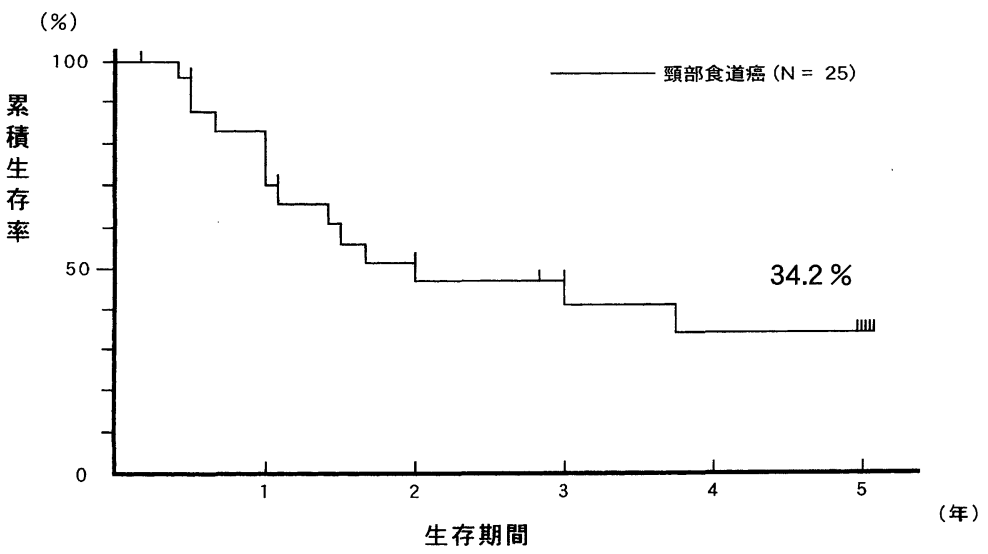

図 1 頸部食道癌の生存曲線 
表 2 咽喉食摘例の治療結果

\begin{tabular}{|c|c|c|c|c|c|c|}
\hline & $\mathrm{n}$ & 腫瘍制御 & $\begin{array}{l}\text { 原発覓 } \\
\text { 残存登 }\end{array}$ & $\begin{array}{l}\text { 頸部リソパ節 } \\
\text { 残存再発 }\end{array}$ & 遠隔転移のみ & $\begin{array}{l}\text { 累積 } 5 \text { 年 } \\
\text { 生存率 }\end{array}$ \\
\hline $\mathrm{T} 1$ & 2 & 1 & 0 & 0 & 1 & \multirow{2}{*}{53.3} \\
\hline $\mathrm{T} 2$ & 4 & 3 & 1 & 0 & 0 & \\
\hline $\mathrm{T} 3$ & 8 & 2 & 1 & 3 & 2 & 15.6 \\
\hline $\mathrm{T} 4$ & 7 & 5 & 2 & 0 & 0 & 66.7 \\
\hline No & 11 & 6 & 1 & 2 & 2 & 40.5 \\
\hline N1 & 10 & 5 & 3 & 1 & 1 & 43.8 \\
\hline RO & 12 & 5 & 3 & 2 & 2 & 36.7 \\
\hline $\mathrm{O}$ & 6 & 4 & 1 & 1 & 0 & \multirow{2}{*}{58.3} \\
\hline OR & 3 & 2 & 0 & 0 & 1 & \\
\hline 計 & 21 & 11 & 4 & 3 & 3 & 41.2 \\
\hline
\end{tabular}

$\mathrm{RO}$ : 術前照射群, O : 手術単独群, OR : 術後照射群

胃管の狭窄， 2 例に胃管咽頭吻合部の小ろら孔を認めた 以外，胃管，腸管の壊死は認めなかった。

根治手術例に打ける頸部リンパ節単独の残存再発は, N0 の頸部廓清非併用の 8 例中 2 例(いずれもルビェー ルリンパ節)に認めたが，一側の頸部廓清を併用した 3 例では認めなかった，一方，N1 例では，頸部廓清非併 用の 2 例中 1 例に残存再発を認めたが，一側廓清の 3 例 および両側廓清の 5 例では認めなかった（表 3 ）。な挔， 両側頸部廓清と同時に $25 \mathrm{~mm}$ 径の孤立性のルビェール リンパ節転移の摘除を施行した 1 例において，45力月の 無病生存が得られた。

食道全拔去例19例の病理組織学的検索の結果, 飛び石 転移病巣は 2 例に認めたの夕であった。交た，一次治療 の際に頸部からのアプローチによる切除を行った 1 例に 打いて，12力月後に下方断端部と胸部食道上部に残存再 発を認めた。また，今回の症例では重複癌の発生は認め なかった。

\section{考察}

下咽頭癌 $\mathrm{T} 1, \mathrm{~T} 2$ 症例の中には放射線で治癒しらる症 例が少なからず存在する。しかし，頸部食道癌の場合に は放射線治療での根治は困難といわれており1)，今回放 射線根治照射を行った症例でも腫瘍制御例はなかった. したがって，頸部食道癌症例では根治手術を主体とした 治療体系が望まれる。

根治手術に際しては，1 ) 食道切除の方法，すなわち 食道の全抜去を行らか頸部のみの切除を行らかの問題,

2 )放射線や化学療法といった併用療法の問題，3 )所属 リンパ節の処理の問題を検討する必要がある.

食道切除の方法に関しては，まず胸部食道に飛び石転 移(壁内転移)が存在する場合には食道全抜去の絶対的適 応となる。

小池 ${ }^{2)}$ は，食道全抜去にて治療した下咽頭・頸部食道 癌12例の組織学的検索の結果， $67 \%$ と高率に胸部食道に 多発癌を認めたと報告している。しかし，その他の報告 での飛び石転移の出現率をみると, 手塚ら゙は下咽頭・

表 3 頸部リンパ廓清の有無と治療結果

\begin{tabular}{|c|c|c|c|c|c|c|}
\hline & & $\mathrm{n}$ & 腫瘍制御 & $\begin{array}{l}\text { 原発巣 } \\
\text { 残存再発 }\end{array}$ & $\begin{array}{l}\text { 頸部リソパ節 } \\
\text { 残存再発 }\end{array}$ & 遠隔転移のみ \\
\hline \multirow[t]{2}{*}{ N0 } & $\mathrm{ND}(-)$ & 8 & 4 & 0 & 2 & 2 \\
\hline & UND & 3 & 2 & 1 & 0 & 0 \\
\hline \multirow[t]{3}{*}{$\mathrm{N} 1$} & $\mathrm{ND}(-)$ & 2 & 1 & 0 & 1 & 0 \\
\hline & UND & 3 & 2 & 1 & 0 & 0 \\
\hline & BND & 5 & 2 & 2 & 0 & 1 \\
\hline
\end{tabular}

$\mathrm{ND}(-)$ : 頸部廓清非併用例, UND : 一側頸部廓清例, BND : 両側頸部廓清例 
頸部食道癌79例のらちの $12.7 \%$, 掛川4) は頸部食道癌64 例のうち $17 \%$ と報告している. 今回の頸部食道癌のみの 集計でも根治手術例21例中 3 例 (14.3\%) と比較的少なか った．したがって，飛び石転移対策として一律に食道全 抜去を行う必要はなく，上部消化管の厳重な検索を行っ たら壳で，食道全抜去例を選択するのが良いと考光られ る.な特, 村上ら5) は, 下咽頭・頸部食道癌の中で C7 を越兄た進展例では飛び石転移が多く, 食道抜去の適応 と述べている。

また，我々は下方断端での切除不足が懸念されるとい ら理由から, Th1 以上の局所進展例飞対して食道全抜 去を行うといら基本方針で臨んだが，結局食道抜去例が 比較的多い結果となった。 今回食道全抜去を行った17例 では, 縱隔での残存再発を 1 例認めたのみであったが, 頸部の久のアプローチでの切除を行った 4 例中 2 例で下 方切除断端の残存再発を認め, 1 例で気管孔周囲再発を 認めた。したがって，頸部食道の原病巣切除に関する限 り, 通常の頸部よりのアプローチよりも食道全抜去の方 が優れていると考兄られる。 しかし，内田ら ${ }^{6)}$ は胸骨切 開を併用することによって上縱隔までの切除は可能であ ると述べて扣り，今回の症例のなかにもこのようなアプ ローチによって制御できた例があったと考兄られ，この 点はさらに検討する必要があると思われた。な执，我々 は頸部よりのアプローチの場合に, 移植腸管と食道との 吻合部での㾇孔形成や移植腸管壊死の際の縱隔内でのト ラブルを懸念していたが，今回の頸部食道癌症例叔よび 以前報告した下咽頭癌手術症例7 飞执いても縦隔内での 合併症は認められなかった。 また，食道全抜去の場合に は, 特に術直後の手術侵壟が大きいことも問題の一つで あり, 術後管理のうえで他科, 特に外科との連携体制が 必須である. 以上述べたよらに, 頸部食道癌では飛び石 転移例や胸部食道に深く進展した例は食道全抜去が絶対 的な適応となるが，その他の例，特に下方断端が Th1 近辺となるような場合には, 胸骨切開を併用して術野を 拡げる方法をとるか，食道全抜去を行らかの選択は他科 との連携を含めて個々の施設の裁量で決定すべきものと 考学る.

術前放射線治療に関して, 内田ら ${ }^{6)}$ は術前照射後の手 術材料の病理組織学的検討の結果, 原病巣に対する放射 線の効果ははなはだ悲観的であると述べている. 今回の 術前照射12例の摘出病理標本をみても, 病理学的 CR が 得られたのは T1N1の 1 例のみであった。また, 術前
照射例の治療成績が手術単独例や術後照射例よりもむし ろ不良な傾向にあったこと，術前放射線治療中に原病巣 が急速に増大した例もあったこと，また術創の治瘉機転 の面からみても，術前照射を積極的に支持する根拠はな いと言わざるをえない。

術前化学療法に関しても, 下咽頭頸部食道癌の予後を 著明に改善するものではないといら意見が多いようであ $3^{8) ~ 11)}$. ᄂかし，小宮山ら ${ }^{12)}$ は下咽頭頸部食道癌に招 いて, 術前 FAR 療法に化学療法を加えることによって $76.2 \%$ といら高い累積 5 年生存率を示し, 手術療法の工 夫で治癒率を上げるには限界があり，今後より抗腫瘍効 果の強い combination therapy の工夫が必要であろらと 述べている.

リンパ節転移に関して, 今回の頸部食道癌症例では $\mathrm{N}$ 陽性例が $48 \%$ であり，先に報告した下咽頭癌症例の 83.1 \%7)に比して低值であった. 頸部食道のリンパ流は下咽 頭と異なり，第一群所属リンパ節は頸部傍食道リンパ節 であり，第二群所属リンパ節が深頸リンパ節である1131). 内田の報告1) でも第一群リンパ節の転移陽性率が第二群 リンパ節の転移陽性率よりも高値を示している。さらに， 第一群リンパ節では小さな陽性リンパ節の方がむしろ多 いとされている6). 今回の症例では根治手術の際に甲状 腺全摘と気管前傍リンパ節の摘除を併用したが，1例で 緹隔リンパ節の残存再発を，1 例で気管孔周囲再発を認 めた。 また，下咽頭癌症例7) では $\mathrm{N} 0$ 症例の予後が良好 であったが，今回の頸部食道癌では $\mathrm{N} 0$ 症例と $\mathrm{N} 1$ 症例 の間での累積 5 年生存率に差異は認められなかった。こ れは頸部廓清を行わなかった $\mathrm{N} 0$ 症例に叔いて，後発の 頸部リンパ節残存再発と遠隔転移が多かったことに起因 していると思われる。これに関連して，内田らは術前転 移 $(-)$ 例でも両側の頸部廓清を行らのが望ましいと述べ ている6). ただし，今回，一側の頸部廓清例でのリンパ 節制御が比較的良好であったことから，早期のもので， 明らか飞病変に左右の局在がある場合には, 両側の甲状 腺切除, 気管傍リンパ節と一側の頸部廓清術を行うこと で制御される例も多いと考光られる。な技今回, 頸部リ ンパ節単独の残存再発例で高率にルビェールリンパ節の 残存再発を伴っていたこと，また根治手術の際にルビ エールリンパ節転移の切除を行った例で 45 カ月の無病生 存が得られたことから, 今後傍咽頭リンパ節廓清の具体 的な手術方法と手術適応を確立する必要があると考兄ら れた。 


$$
\text { まとめ }
$$

1983年から1995年までに札幌医科大学耳鼻咽喉科にて 治療を行った頸部食道癌25例を対象に臨床的検討を行い, 以下の結果が得られた.

1 . 累積 5 年生存率は全体で $34.2 \%$ であり, M1 症例 を除く根治治療例 24 例では35.8\%, 根治手術例21例では $41.2 \%$ であった.

2. 根治手術群に和ける原発巣の制御に関しては, 食 道全抜去を行った例が頸部のみのアプローチ例よりも良 好であった。

3. 根治手術の際に頸部廓清術を併用した例では, 頸 部単独の残存再発を認めなかった。

4. 術前照射例の累積 5 年生存率は $36.7 \%$, 手術単独 例と術後照射例をあわせたものでは58.3\%であった。

\section{参考文献}

1) 内田正興 : 消化器癌の㡎断と治療最近の知見 4 一下咽頭 ・頸部食道癌一. 癌の臨床 $32: 1119 \sim 1123,1986$.

2 ) 小池聡之: 同時多重がん治療上の問題点, 下咽頭癌に和け る治療方針. 頭頸部腫瘍 $19: 337 \sim 341,1993$.

3 ) 手塚克彦, 丹生健一, 市村恵一: 下咽頭癌と食道癌の重複 例に対する治療経験. 頭頸部腫瘍 $21: 115 \sim 119,1995$.

4) 掛川てる夫 : 下咽頭 - 頸部食道癌治療の進歩 4 一頸部食道 癌の外科治療一. 気食 $34: 141 \sim 147,1983$.

5 ）村上 泰, 猪狩武詔, 原口茂徳, 他: 下咽頭に及ぶ頸部食
道癌診断治療の現況. 消化器外科 $6: 527 \sim 534,1983$.

6 ) 内田正興, 加藤孝邦, 河西信勝, 他 : 下咽頭 - 頸部食道癌 治療の進歩 3 一進展病理と転移から眺めた手術法一. 気 食 $34: 135 \sim 140,1983$.

7 ) 朝倉光司, 氷見徹夫, 原㴊保明, 他 : 下咽頭 - 頸部食道癌 の臨床的検討. 日耳鼻 $101: 44 \sim 52,1998$.

8 ）堀内正敏, 飯田政弘, 田村喜之, 他 : Neo-adjuvant 化学 療法を併用した切除可能な頭頸部癌症例の予後. 耳鼻 39 : 848 852, 1993.

9 ) 保喜克文, 川端一喜, 鎌田信悦: 癌研頭頸科に特ける neoadjuvant chemotherapy (NAC) について. 耳鼻 $39: 864$ $\sim 869,1993$.

10）稲木勝英, 高橋廣臣, 岡本牧人, 他：当科に拈ける Neoadjuvant chemotherapy の経験. 耳鼻 $39: 841 \sim 847,1993$.

11）犬山征夫：頭頸部癌に対する neoadjuvant chemotherapy. 耳鼻臨床 $82: 1043 \sim 1050,1989$.

12）小宮山荘太郎, 益田明典, 冨田吉信, 他: 下咽頭癌の集学 的治療 一下咽頭癌の遠隔成績の向上一. 癌と化学療法 18 : 2090 2094, 1991.

13）猪狩武詔：下咽頭癌の頸部リンパ節転移に関する基礎的並 びそ臨床的研究. 日耳鼻 $89: 627 \sim 640,1986$.

$$
\left.\begin{array}{l}
\text { 原稿受付 : 平成 } 10 \text { 年 } 7 \text { 月 } 30 \text { 日 } \\
\text { 原稿採択 : 平成 } 10 \text { 年 } 9 \text { 月 } 9 \text { 日 } \\
\text { 別刷請求先 : 朝倉光司 } \\
\text { 干 } 051-8512 \text { 北海道室蘭市山手町3-8-1 } \\
\text { 市立室蘭総合病院耳鼻咽喉科 }
\end{array}\right)
$$

